\title{
Catastrophes and Weddings. Chachi Ritual as Metamorphosis
}

Istvan Praet

\section{(2) OpenEdition \\ Journals}

Electronic version

URL: https://journals.openedition.org/jsa/12840

DOI: 10.4000/jsa. 12840

ISSN: 1957-7842

\section{Publisher}

Société des américanistes

\section{Printed version}

Date of publication: 5 December 2009

Number of pages: 71-89

ISSN: 0037-9174

\section{Electronic reference}

Istvan Praet, "Catastrophes and Weddings. Chachi Ritual as Metamorphosis", Journal de la Sociéte des américanistes [Online], 95-2 | 2009, Online since 10 December 2014, connection on 04 September 2022. URL: http://journals. openedition. org/jsa/12840 ; DOI: https://doi.org/10.4000/jsa. 12840 


\title{
CATASTROPHES AND WEDDINGS. CHACHI RITUAL ASMETAMORPHOSIS
}

\author{
Istvan PRAET *
}

A question that has intrigued anthropologists for a long time is why catastrophic anxieties are so omnipresent among Amerindian peoples. Known in the literature as " millenarianism », fears of an apocalypse appear time and again, both in lowland and highland South America. This article aims to contribute to a better understanding of this phenomenon by examining notions of metamorphosis or "shape-shifting ». The particular case described examines the link between catastrophes and the wedding festival of the Chachi, Amerindians from the Pacific coast of Ecuador. [Key words: metamorphosis, ritual, millenarianism, conceptions of disaster, Chachi Indians.]

Catastrophes et mariages. Rituels chachi et métamorphoses. L'omniprésence des angoisses de catastrophes chez les peuples amérindiens intrigue les anthropologues depuis longtemps. Connue dans la littérature sous le nom de "millénarisme», la crainte d'une apocalypse est récurrente dans toute l'Amérique du Sud. Cet article entend contribuer à une meilleure compréhension de ce phénomène en s'intéressant aux notions relatives à la métamorphose. Plus particulièrement, il explore le lien entre catastrophes et fêtes de mariage chez les Chachi, un groupe amérindien de la côte pacifique équatorienne. [Mots-clés: métamorphose, rituel, millénarisme, conceptions de la catastrophe, Chachi.]

Desastres y bodas. Rituales chachis como metamórfosis. Una cuestión que ha intrigado a los antropólogos desde hace mucho tiempo es la omnipresencia de ansiedades catastróficas entre los pueblos amerindios. Conocidos en la literatura como « milenarismo ", los temores de un apocalipsis aparecen en todas partes de América del Sur. Este artículo se propone contribuir a una mejor comprensión de este fenómeno mediante el examen de nociones relacionadas con la metamórfosis. Más concretamente, la investigación se centra en la relación entre las catástrofes y las bodas de los chachis, un grupo indígena de la costa del Pacífico de Ecuador. [Palabras claves: metamórfosis, rituales, milenarismo, concepciones del desastre, chachis.]

* Postdoctoral Research Fellow, University of Oxford and Laboratoire d'anthropologie sociale, Paris. Linacre College, St Cross Road, Oxford OX1 3JA, UK [istvan.praet@linacre.ox.ac.uk].

Journal de la Société des Américanistes, 2009, 95-2, pp. 71-89. O Société des Américanistes. 


\title{
Catastrophes
}

On the 31st of December 1999 frantic crowds had gathered in San Miguel, one of the foremost ceremonial centres of the Chachi. These inhabitants of the coastal lowlands of Esmeraldas, Ecuador, had congregated because they feared the world would end there and then. Some had picked up on the prophecies of doom concerning the new millennium and this had quickly developed into a general feeling of terror. Incidentally, there had been intense volcanic activity at that time and the sky was darker than usual. Many were convinced that an enormous deluge or a devastating earthquake would follow. What happened during these panic-stricken moments was intriguing: the Chachi organised a mock wedding festival. Musicians brought marimbas and various kinds of drums and played continuously. One of the participants declared afterwards: " We had to do this; otherwise God-the-Father would have destroyed us all ». Another one described it thus:

\begin{abstract}
We were all there and kept an eye on the clock. As it got closer to midnight, we became more and more anxious. Just before twelve everybody was nervously checking their watches. A few had small portable radios and listened attentively. Some were so distressed that they started crying. At 12 o'clock nothing happened, no flood, no earthquake... A big relief, but we decided to stay on for a while, to be entirely sure that nothing would happen.
\end{abstract}

Anxieties about an imminent apocalypse are widespread, not only among the Chachi, but among Amerindian peoples in general. For our purposes here it suffices to consider a few examples from the ethnography of South America. Neil Whitehead (2002, p. 133) has shown that fears about the new millennium led to an outbreak of panic among the Patamuna, very reminiscent to the Chachi fears about the year 2000. Robin Wright $(1992,1998,2004)$ has amply documented Baniwa « millenarianism ». A key point he makes is that contemporary ideas about disaster cannot be understood as a mere consequence of recent Christian influences. Rather, they are reformulations of something which already existed previously. Stephen Hugh-Jones (1994) reaches a similar conclusion with his claim that Tukanoan messianic cults resemble both the indigenous shamanism of the area and Catholic belief. But not only Amazonia specialists have documented such apocalyptic ideas. The theme is prevalent among Andean populations as well. Sabine MacCormack (1988, pp. 982-983) provides an historical illustration with her discussion of the Quechua concept of pachacuti, which she describes as " the world turning upside down ». A more contemporary example is offered by Olivia Harris (1987, p. 94), who found the Laymi of the Bolivian Andes to be " obsessed with rumours about the end of the world". In sum, we notice a broadly parallel conception of the apocalypse across native South America. But why would this be so? The aim of the present study is to contribute to this 
general question by looking at the specific conceptions of disaster of the Chachi, whom I now introduce briefly.

Formerly known as « Cayapa », the indigenous inhabitants of Esmeraldas, Ecuador's northernmost province on the Pacific coast, nowadays refer to themselves as « Chachi ». Their language, Cha'palaa, is spoken by approximately nine thousand people. In a largely Hispanic country, the Chachi constitute a relatively sizable minority group; they have a particular reputation for their skills as canoe crafters, basket weavers, hunters and river fishers. While most of them have a preference for living far away in the forest, they are by no means an entirely isolated group. They have always maintained connections with outsiders, both along the Pacific coast and in the Andean highlands (Altschuler 1964, p. 20; Carrasco 1988, p. 22). Recent linguistic evidence indicates that the Chachi are relatively closely related to the Tsachila, the native residents of the Santo Domingo area in the western foothills of the Andes (Curnow and Liddicoat 1998). According to the same study, they are also related to the Awá of the western Colombian-Ecuadorian border area and to certain groups in the Paez region (highland Colombia). In a geographical sense, they live close to the Afro-Ecuadorian populations of Esmeraldas, to the Embera of the Colombian Chocó and to the Quichua of the highland province Imbabura. How and to what extent the Chachi are connected to these various groups remains largely unexplored. At present, most Chachi people speak Spanish fluently, a result of the continuing efforts of bilingual teachers trained by organisations like the Summer Institute of Linguistics. While a significant number of them has migrated to Esmeraldas town and other cities in recent years, the overwhelming majority continues to live in their ancestral territories contiguous to the CotacachiCayapas nature reserve.

To say that the Chachi have an " obsession » with disaster is not an exaggeration. Many Chachi people can describe in minute detail how catastrophes took place in the past. On one occasion, it is told, there was a solar eclipse. When the whole world had become dark, frightening events began to occur. All kinds of objects such as stones or axes started flying around like insects. Suddenly, trees could talk. The Chachi were totally confused. In the darkness, they could no longer find their way. As they could no longer look for nourishment, they got very hungry. Some fruit trees and certain palms were friends of the Chachi. They gave instructions about how to locate them: «I am here. If you want to eat something come over here. Here I am! » But not all trees were so friendly; they were helped only by those that they always treated well. The trees they used to chop down (to make canoes or sleeping mats, for instance) turned against them and were out for revenge. Benefiting from the dark, giant ogres lifted up the roofs of houses, abducting and eating many defenceless people. Some Chachi turned into maneaters. Brothers ate their sisters and sons ate their fathers. Mothers even ate their little babies. In one woman's words: « As it was dark, people could not see what 
they ate. Their own relatives had begun to smell like pineapple, so they were under the delusion that they were consuming fruit ». After the eclipse, a huge thunderstorm followed which turned into a hurricane. Axes flew around, trying to kill the Chachi. They had always been "maltreated » (by knocking them against trees and so on) and now it was their moment of vengeance. And it was not just axes. All objects that people were accustomed to « maltreat » now became dangerously inimical. The stones they occupy to grind plantains now tried to smash the Chachi. A whole variety of kitchen utensils transformed into lethal projectiles. Pots, plates and spoons attacked people. These were all angry as in everyday life they had been burnt with fire (the pots), badly treated by filling them with hot substances (the plates) or tortured by stirring them in boiling food (the spoons). Many people died, but some survived as they were helped by friendly objects, that is, objects they had always treated with care and affection ${ }^{1}$. "During such catastrophes", one man told me, "it is as if the whole world reverses". He maintained that while tornadoes uproot the heaviest trees, the lightest species remain unharmed. Guayacan trees, known to be the sturdiest in the area, were drifting through the air like feathers on various occasions in the past. Balsa, which has the lightest kind of wood, becomes like a stone and people run for shelter under such trees ${ }^{2}$. Moreover, animals usually hunted by people allegedly turn into redoubtable enemies; prey becomes predator. Opossums, peccaries and wildcats attack humans, bats suck their blood and owls eat their eyes.

Accounts of the apocalypse also involve earthquakes. On various occasions, trees fell, houses collapsed and people got smashed. Certain quakes were allegedly so devastating that some houses simply vanished in the ground. Remarkably, those who endured such crises best were not the new and sturdy houses - as one would expect - but the old and shabby ones. Again, we are confronted with a reversal: during the catastrophe what is sturdy becomes weak and vice versa. The idea of a reversal of the world is also brought up by my predecessor Samuel Barrett (1925, p. 376), who links earthquakes to the appearance of «those without anus », monstrous beings which cannot eat proper food and instead feed on the steam escaping from cooking pots. One of my informants described an earthquake that took place some 15 years ago, when he was in his native village. It was a horrible experience. Houses were shaking and the pots in the kitchens fell down. People ran outside in panic. They were jumping, screaming and crying in fear, for they all assumed it was the end of the world. After such an incident people usually hurry to the ceremonial centre, where they enter the church, kneel and beg God-the-Father for mercy ${ }^{3}$. Floods and tsunamis (locally known as visitas) are also recurring elements. One bilingual teacher recounted me what happened during a massive flood in 1972, when he was living in Rio Cayapas. It was a general disaster; never before had he seen something so terrible. For days in a row, there was a superabundant rainfall. The river burst its banks and entire houses were swept away. Villages along the river had to be evacuated and people 
had to camp in places that were located higher up. Various Chachi got caught by the violent currents and drowned. More recently, in 2003, another calamitous flood occurred in Rio Cayapas. Although no people appear to have drowned, many lost domestic animals and other possessions. Just as during the 1972 flood, those who were most frightened went to the ceremonial centre to drum and to play marimba.

This illustrates that New Year 2000 was not the only time that a fiesta was organised. In fact, any catastrophe of significant proportions is consistently followed by a celebration in the ceremonial centre. Consider the following account, recorded by Milton Altschuler (1964, p. 117):

During 1959-1960 rumors were constantly in the air in Ecuador that the end of the world was going to take place soon. These rumors had reached the Cayapa [the former name of the ethnic group nowadays known as "Chachi »] According to Gabriel [a prominent Chachi], Jesus carries the world in his arms and when the sins of the people pile up, the world gets heavier and heavier until at last the burden becomes insupportable, and Jesus lets the world fall. That, said Gabriel, will happen very soon unless the Cayapa can appease the wrath of God by holding a special fiesta [...]. Gabriel was so concerned that he sent a message to the chiefs of the other sections [that is, to the Governors of the other ceremonial centres], inviting them to a meeting at his home to discuss the impending disaster and the means by which to avert it. He wanted each group to stage a fiesta at its own ceremonial center at the same time " to give added strength ». To make doubly sure, he wanted four young children to be married " as they did in the old days ». Being young they would, of course, be without sin, and Jesus would find the sight touching and forgive the world.

The coincidence of ritual celebrations with circumstances of general panic is a well known fact and has been widely documented in the ethnography of South America. What surprises here is the Chachi's particular choice for weddings, occasions which non-Chachi generally tend to envisage as joyous. Why celebrate a wedding when you are struck by the worst misery? When I asked this directly, none of my informants could give a univocal answer. Phenomena like solar eclipses, some explained to me, are a warning for people who live badly. All catastrophes are a punishment of God-the-Father or; as some literally express it, they are a whipping. He chastises in retaliation for all the sins people have committed. It is up to the Chachi to beg God for forgiveness (alabar a Dios) and to better their lives. All my informants agreed that the best way to prevent the destruction of the world is to organize a wedding fiesta. In relatively small emergencies like the 2003 flood people may content themselves with mimicking a marriage and just play the instruments and dance. When the worst comes to the worst, however; that is not enough. Nothing less than a real wedding will do. Preferably, there should even be several weddings at once. The couples that are planning to get married anyway are obvious candidates. When no couples were 
available, the elderly used to summon particular youths to marry, if they wanted or not. If the situation was extremely precarious it even happened that they married young children ${ }^{4}$. But these specifications do not resolve the question of the link between disasters and getting married. In the next section I attempt to clarify the issue by looking at the weddings themselves.

\section{WEDDINGS}

To be sure, weddings are not improvised to deal with a calamity in ordinary circumstances. Usually, they are planned long beforehand and take place at fixed times of the year. They are celebrated in the ceremonial centres at Easter or at Christmas. Weddings are considered extremely important: they involve considerable preparation and, by local standards, incredible expenses ${ }^{5}$. It involves buying rum (ishkala), sugar to make maize beer (chicha), tobacco and candles. Those who are getting married and their " wedding godparents », the madrina and the padrino, jointly finance most of the celebration. What happens during the preparatory phase of the weddings gives us some clues about the relation with disaster. In the days before the Easter weddings one must act cautiously, for it is thought that "Christ's protection has fallen away " ${ }^{6}$. For instance, bathing in the river should be avoided. The prohibition may be largely ignored nowadays, but many people believe that in the past those who did go into the river turned into all kinds of animals and monsters. Myths tell of imprudent Chachi who metamorphosed into dolphins, lizards, toads and dragons. Besides bathing in the river; walking in the forest must be kept to a minimum. Without Christ's protection, all kinds of accidents are likely to happen. There is an increased risk of being bitten by venomous snakes, which all of a sudden seem to abound. If one goes out alone on the night of Good Friday one is bound to run into various kinds of malicious goblins, who perform beautiful music. Marimba-playing and guitar-playing goblins are reported; for every type of music instrument a goblin appears to exist. Notably, these are envisaged as reversed beings. When one hears their music vague and distantly, they are, in fact, nearby. When they sound loud and clear, by contrast, they are far away. If one thinks that one is dangerously close, one is safe. If one thinks that one is safely distant, one is in danger. Those who are assaulted by such a goblin but manage to survive are said to return as virtuoso musicians, even though they may never have touched an instrument before. People also refer to «drumming ghosts », evil creatures with characteristics of both humans and music instruments. They are said to have a hole at the front of their rib cage, from which blood is constantly dripping. If one looks inside there is nothing: no flesh, no organs. They are hollow. Their back, however, is very hard, more or less like the surface of a drum. They have whips which they use to flagellate themselves (this is said to cause the sound of drumming). In brief, the likelihood of running 
into all kinds of inimical creatures increases dramatically in the week before Easter. "All are afraid to leave their house in that particular week », one man assured me. Indeed, what happens in the days before Easter could be envisaged as a « little catastrophe ». I now turn to the wedding ritual itself.

Only a small crowd was present when the bell of the church chimed for the first time on Good Friday in April 2004. It was noon and we were in the San Miguel ceremonial centre. "This is the hour that Jesus died ", I was told. Some of the men took the big crucifix from the sanctuary and put it horizontally on the church floor. Others lit candles in the shrine with the saints' figures. In front of the crucifix, four men positioned themselves with long sticks, thus blocking the entrance of the church. A member of my host family explained me about this: " Those men with their sticks are guardians. As Jesus is dead and defenceless now, we have to protect him. If we do not, the devil and his consorts would come and take him away. That would be disastrous ». The stick-bearers had to remain on post until midnight, that is, "until the moment that Jesus resurrected ». In the afternoon people occasionally went in front of the church altar, lit a candle and said their prayers. In the vernacular this activity is referred to as utyakenu; it consists of uttering incomprehensible phrases reminiscent of the esoteric incantations of shamans who cure the sick. By the time the vigil in the church had come to an end, a substantial crowd had gathered in the ceremonial house. Most of them were Chachi, but several Blacks from neighbouring villages were also present. There was a marimba, several kumumus (small drums) and two bombos (big drums). During the first night, those who would get married were not yet present and little happened. Music was played until dawn, people smoked tobacco and some got drunk.

The brides and the grooms arrived early the following morning. At the event that I witnessed there were four pairs. In the ceremonial house, the brides sat on one side of a bamboo partition, the grooms on the other. Their outfits were strikingly colourful. The brides had glittery dresses, while their face and the upper part of their body were covered by a veil. The veils were kept in place by headbands to which strips of old coins and tinsel garlands were attached. Some had festoons of little plastic bells, all in extravagant tints of gold, silver, green and red. The grooms wore two red ribbons which they put crosswise over their shirts. They also had headbands of the same colour and a few had put a red handkerchief on top of their head. The godparents of each pair, those who direct the fiesta, were always close. Behind the brides sat their respective madrinas, who constantly remained by their side. Likewise, each groom was accompanied by a padrino. The ceremonial house was divided in a female and a male part: the women mostly stood or sat behind the madrinas, the men were grouped at the side of the padrinos. The dancing was initiated by the godparents, who opened with their respective brides or grooms. Then, friends and relatives of the couples could begin. The same procedure was repeated every time. If a man from the audience 
wished to dance, he offered a soft-drink, beer or some rum, first to the groom, then to the bride on the other side of the bamboo partition. With the help of her madrina, the bride put on a ceremonial dress. Wrapped up in her veil, she avoided all eye-contact with the giver; the onlookers could only see her nose peeping out of the cloth. Thus, she danced with the man. Most dances only lasted for ten seconds or so. The two dancers stand close, facing each other. While the man merely walks backwards and forwards a couple of times, the bride - following him closely - hops rhythmically and sways her arms ? ${ }^{7}$ The wedding couples and their godparents remained sober, for they are supposed to « dance well ». The rest of those present, the relatives and friends, gradually got more and more drunk. Each time they danced, they were served rum by both the bride and the groom. Some, both women and men, ended up so drunk that they almost lost consciousness. Once in a while, some of the men who had too much to drink engaged in brawls. It was the task of the Policemen (chaitarukula) to punish those who were overly excited and they did not hesitate to put incorrigible fighters into the stocks ${ }^{8}$. To me, such drunken and sometimes violent behaviour was very striking, for it contrasted starkly with my experience of how Chachi act in ordinary life.

There were pauses in the dancing once in a while, but the music always continued. The padrinos were responsible to make sure that the musicians had sufficient rum and cigarettes at their disposal. The brides retired briefly with their madrinas every hour or so. When they reappeared, they would wear a new veil, different but similarly colourful. « They are like film stars », one friend remarked, " during the wedding, they constantly change from one dazzling outfit into the other ». Remarkably, the madrinas always followed their brides closely and never left their side. Even when the bride has to defecate, I was told, she is accompanied. When I asked about this one participant responded by recounting a myth. Summarized, it came down to the idea that brides (but also grooms) would behave promiscuously if they were not guarded ${ }^{9}$. Towards the end of the fiesta, the attention was drawn at the Policemen. As they took their whips, a stir went through the crowd. It was time for the general punishment. The Policemen chastised gently, not severely as they would when somebody had truly committed a mistake ${ }^{10}$. Nobody was exempted: the newlyweds, the godparents, the elderly, women and children all received at least one whiplash. All had to be chastised, it was said, because all had sinned in the past year. By being whipped, I was told, one's sins (ujcha) were forgiven. Those who tried evading it were tracked down and received an extra portion. After this rather turbulent intermezzo, the fiesta resumed as before. The music went on the whole evening and throughout the night. Near dawn, those who were still capable performed the closing dance, known as San Fan Fan, a derivation from the Spanish «San Juan ». This was the only time at which people danced collectively: brides, grooms, godparents, wedding guests and even the musicians participated. Drums and the marimba were 
carried along. It was, to use Barrett's $(1925$, p. 326) expression, « a riot of fun and jollity ». The dancers exchanged instruments, bottles of rum and pieces of their outfits. They also cracked risqué jokes and shouted mock insults. For instance, they would say to the groom: "Your wife is sleeping around ». This outburst of noise and laughter marked the end of the wedding. Brides and grooms took off their ceremonial finery and put on their ordinary clothes.

\section{The Big Metamorphosis}

What happens at the Easter celebration, I suggest, can fruitfully be understood as a metamorphosis. In fact, it is the ultimate metamorphosis or, in any case, a big metamorphosis. What takes place is a mass shape-shifting whereby all Humans turn into Monsters and Ghosts. The Living turn into the Dead ${ }^{11}$. Strictly speaking, " Chachi society » ceases to exist. Indeed, weddings are catastrophes. Before explaining what exactly I mean by this, I wish to emphasize a couple of points. The lavish and conspicuous spending of money is something which usually only happens at weddings and a few other occasions commonly qualified as « ritual ». Similarly, the copious consumption of rum and tobacco is fairly strictly limited to such instances ${ }^{12}$. In ordinary circumstances most Chachi people never smoke or get drunk, a significant contrast with what happens among neighbouring (non-Amerindian) populations. Another important element is the frequent use of esoteric language. When people go to the church in the ceremonial centre, they " pray » in a twisted idiom of exotic and archaic terms that have no clear meaning in the vernacular. If asked about these incantations, most of those who had been uttering them simply deny that they know them; they are « words of the devil » and sharing them would be dangerous. Another highly significant element is that the weddings are celebrated in ceremonial centres or pebulu, which literally means " village of the dead ». Most of the year such centres stand empty; people do not live there. They are used only on special occasions, mainly weddings and burials. Indeed, these places are also graveyards: the dead are buried underneath the ceremonial house. In many respects these villages of the dead constitute a miniature version of the ordinary Chachi world (DeBoer 1997), even though most things appear to be inverted. Thus, the ancient centres are not built on random places along the river, but specifically where the current is obstructed and the water goes the other way round. Chachi people explicitly avoid building their houses near such spots; they always live where the current is uninterrupted. Its implantation near whirlpools makes the ceremonial centre, in a very physical sense, a " place of the opposite ».

In previous work (Praet 2006, pp. 224-281) I have argued at length that these various practices and the very location where the weddings take place mark a temporary change from the Human into the non-Human; all Chachi have become Monsters. Humans or Chachi shift shape. I will not repeat this argument 
in detail. For my purposes here I will just highlight a few key insights. Before anything else, it is necessary to clarify why I use the terms "Human » and "Chachi » interchangeably. At present, the latter expression is often used as what anthropologists call an " ethnonym ", the name of a specific indigenous group. However; this usage is of relatively recent origin and mostly restricted to those with close links with the Hispanic world. When asked to translate the term " Chachi », my informants usually rendered it simply as " people» (gente) or " true people» (gente verdadera). In that sense, "Chachi » does not refer to a particular group of humans but to humans in general. In such a framework, it would appear that there are no other humans apart from the Chachi ${ }^{13}$. To bring across this particular conception of humanity I capitalize «Humans ». Elsewhere (Praet 2005, 2006, 2009) I have proposed that «Chachi" or " Humans » must be conceived of as a shape: these notions do not so much refer to a certain class or an ontological category, but to a position characterized by a specific mode of behaviour which my informants often epitomized in the phrase ura'chumu, " living well ». Among other things, this entails a strictly monogamous lifestyle and an attitude of modesty, that is, abstaining from alcohol and tobacco. Chachi shape or Human shape is prominently opposed to Monster shape or Ghost shape, often captured in the phrase firu'chumu, "living badly ». The latter principally refers to promiscuity, a general lack of restraint and a propensity for torture and aggression ${ }^{14}$. If one accepts these respective definitions, the wedding ritual, characterized by out-of-character violence, drunkenness, excessive smoking and whippings, is literally an instance of generalized shape-shifting.

The wedding festival at Easter always seems to be announced by what one could call an "institutionalised disaster ». If serious catastrophes are always followed by weddings, weddings are also always preceded by catastrophes. It is during Holy Week, especially, that people report being bitten by poisonous snakes. It is in the days before Easter that people avoid trips in the forest or bathing in the river because they are scared to encounter all kinds of inimical creatures such as drumming ghosts. To be precise, Chachi people are not exactly afraid of such Monsters. Rather, fear is turning into a Monster against one's own will (Praet 2006, pp. 74-121). Assaults by music-playing goblins should be understood as metamorphoses: the people who survive return as goblins themselves. Hence the fact that they are envisaged as virtuoso musicians. It is no surprise that the link between weddings and metamorphoses is one of the most frequently recurring themes in myth ${ }^{15}$. Consider the example of pipini, an aquatic Monster which is thought to be the cause of both drought and flooding:

During a celebration in Punta Venado [the most ancient ceremonial centre] an unknown man appeared. Nobody knew he was a man-eater; he had the habit of eating Chachi fishermen. Dressed in beautiful, glittering clothes, he was so handsome that one of the girls wanted to marry him immediately. Preparations for the wedding were taken and at one point the man took off his clothes, which were entirely made of silver coins. 
That was the snake shedding its skin, but the girl did not notice. The beautiful man appeared to be incredibly thirsty. He asked to fill a canoe with water and to bring it in the ceremonial house. After drinking several canoes of water, which he experienced as consuming rum, the river almost dried up [Punta Venado is located along the Rio Cayapas]. Then, people started to suspect that he might be pipini, the giant snake that inhales and vomits water. When they remarked: « You drink so much, you are just like a water dragon " he got angry, took his wife and ran away towards the coast. They jumped into the sea and both transformed into water dragons.

What happens at the " real » wedding ritual I have described is actually not so different, for we have a complete reversal into the monstrous there too; all Humans turn into Monsters and Ghosts. The first day of the festival could be understood as a vigil of cosmic proportions. As the horizontal position of the crucifix indicates, God himself has died. Those guarding Christ's corpse are not Chachi but Ghosts. Those sitting in the church are not the Living but the Dead. Everybody present in the ceremonial centre, which is a graveyard after all, is Dead. For the procedure to be successful, both the victim and the rescuers must share a similar shape. An interesting pattern emerges: in order to rescue the dead Christ, one has to become Dead oneself. Throughout the fiesta, the musicians are given great amounts of alcohol and tobacco. They are Monsters, and it need not surprise us that especially at this time of the year all sorts of hybrid creatures with features of music instruments are spotted. At the fiesta the status of the musicians is identical to that of marimba-playing goblins and drumming ghosts. Recall that such ghosts are imagined as flagellating creatures. This is exactly what happens at the weddings: some of the participants chastise themselves. I stress that the music performed at the ceremonies is restricted to those occasions. One would never come across such an ensemble in everyday life. Music marks the non-Human shape of all those present.

Brides and grooms arrive on the second day of the festival. One is readily struck by their eccentric outfits. The brides' frequent changing of clothes (« Just like film divas ») suggests the assumption of not just one but a sequence of various non-Human shapes. It is perhaps no coincidence that the term for " changing one's clothes » is the same as that for " metamorphosing " (mandimu). In any case, shape-shifters are very often depicted as wearing exceptionally colourful and glittery outfits in mythical accounts. Another striking element is the fact that the couples are constantly accompanied by their wedding godparents. The way things are staged is distinctly paradoxical. On the one hand, the newlyweds are supposed to " behave properly » and "live well », something the Policemen constantly insist on. Each pair is married by a godparent pair that has already proven to be a worthy couple ${ }^{16}$. On the other hand, brides and grooms are treated as incorrigible sinners: hence the idea that they should be closely guarded. While supposed to be strictly monogamous, the newlyweds are explicitly 
depicted as sexually voracious. That the brides have to wear a veil and are forbidden to even just glimpse at other men confirms that they are envisaged as the worst adulterers imaginable (girls never wear veils in ordinary circumstances). That the wedding partners are identified with dogs or other animals that epitomize promiscuity is a further illustration. Now adultery is seen as one of the vilest crimes possible and, therefore, harshly punished by the Policemen. The sanctions of whipping and putting people in the stocks become better understandable if we grasp that committing a mistake against marital faith implies losing one's Human shape (Praet 2009). Those who « sin » are no longer Chachi; adultery is equivalent to monstrosity. In short, the brides and grooms shift from Humans into Monsters ${ }^{17}$. The position of those offering rum and soft drinks is similar to that of the wedding couple: they are no longer Human. More generally, I argue that all wedding-participants temporarily become non-Humans. Their often immoderate consumption of rum and tobacco, their sometimes wild and aggressive behaviour and their dancing with bride or groom indicate their monstrosity. Dancing is associated with adulterous sex. In that sense, the wedding can be understood as a collective orgy; it is defined in opposition to the monogamous restraint of everyday life. All dancers are « sinners » or, what amounts to saying the same, they are Monsters. Especially the wedding couples and the godparents manifest themselves as such: they are the ones that dance most often. Little wonder, given the outburst of " sinning » at these particular occasions, that the Policemen are so busy whipping and chastising. During the general punishment neither the Policemen nor those whom they whip are Humans. In fact, torturing is a conspicuously non-Chachi way of acting; in ordinary circumstances, the exemplary peacefulness of the Chachi is stressed time and again. This attitude is often contrasted with the ostentatious aggressiveness of fearsome outsiders such as the colonial Spaniards or policías. Spaniards, whether soldiers or clerics, were considered to be man-eaters, implying that they were not Human (see Praet 2006, pp. 77-85). In other words, Policemen are Spaniard-like Monsters. Those whom they punish, the "sinners », are in acute danger of losing their Human status forever. The aim of the whipping is precisely to counter this: the sinner/Monster has to be drawn back into his or her Human shape. To accomplish this the punisher has to assume the same position as the culprit: from the ordinary Chachi that he is in everyday life, he transforms into an Hispanic Monster, a Policeman. That is why he mutters archaic Spanish incantations and tends to wear old-style colonial outfits on such occasions. In my view, the ultimate aim for both the punished and the punisher is to cast off their Monster shape definitively. In other words, I contend that the Policeman is an expert shape-shifter who guides the sinner back into his former shape. The pattern that emerges is similar to what we have seen before: in order to reassume one's humanity and to ward off the monstrous, one temporarily has to turn into a Monster. That is, adopting a similar viewpoint as one's adversaries is a necessary precondition to deal with 
and, eventually, to overcome the difficulties they provoke. As we know from contemporary Amazonian anthropology, this idea is quite widespread across South America. What matters is who manages to manipulate the " perspective ", as Eduardo Viveiros de Castro (1998) has expressed it. To formulate what happens during the punishment in his terms: the Policeman transforms into a Monster but only with the aim to impose his own (Chachi/ Human) perspective in the end. In order to dominate the metamorphosis one first needs to be « on equal terms " with one's non-Human adversary; the implicit logic is that one can only beat the monstrous by first joining it.

The San Fan Fan closing dance is the climax of the metamorphosis. One last time, in a jolly charade of fun and drunkenness, the dancers demonstrate their monstrosity. They jokingly insult each other, accusing their fellow dancers of sleeping around. As pointed out, acting adulterously is equivalent to acting monstrously. The riotous exchange of instruments, hats and other items amounts to a sequential shifting into a multiplicity of non-Human shapes. Among them, as they dance in a long queue, is that of a water dragon (this elucidates the glittery costume of such giant snakes in myth, for many participants are adorned with silver coins and colourful beads). Others embody fearsome Spaniards, marimbaplaying goblins and drumming ghosts. In short, the closing dance highlights the position of the wedding participants as Monsters and Ghosts. It is the final episode of a concrete and tangible catastrophe where the Living have all become Dead, an idea that is less strange than it may appear at first sight for, after all, the wedding takes place in the graveyard. The end of the whole event is marked by the wedding couple changing into their ordinary outfits: only then the world has turned back to normal. The ceremonial centre is vacated, people look for their canoes and return home: without more ado, Monsters and Ghosts transform into Humans again. It is worth repeating that the vernacular expression for « changing back into one's former clothes » is identical to that for " metamorphosing ». Arguably, what happens during weddings is identical to what takes place during « real » catastrophes. Earthquakes, floods or hurricanes are equally envisaged as metamorphoses. People, animals, plants and things shift shape. Hence the "cannibalism ». As I indicated earlier, eating human flesh is non-Human behaviour par excellence: those who confound their babies for pineapples are no longer Humans but Monsters. Hence the fact that innocuous animals become dangerous, peccaries hunt Chachi, bats suck their blood and so forth. What happens is a generalized shift from prey into predator, victim into attacker. The same procedure takes place when certain trees transform into giant ogres and objects like pots, spoons and axes turn aggressive. Those who the Chachi « maltreat » in ordinary circumstances now take revenge and torture their torturers. The " turning around » of the world - what is sturdy becomes shabby, what is light becomes heavy, etc. - is yet another expression of this generalized metamorphosis. We are now in a position to better understand the link between weddings and 
catastrophes. During the festival, the site of the ceremonial centre is conceived of as the entire world. Indeed, Chachi people often say that the world rests on wooden crosses, just as the ceremonial house where the dancing takes place is built on top of the graveyard, i.e. « supported by crosses ». Wedding participants explained me that each time somebody commits a mistake the weight of the world augments and crosses are liable to snap. Each cross that breaks causes an earthquake or other disasters. Adulterers, it is said, " have no cross » (cuusa tajtu). When the " burden of sins » becomes too heavy, Godly punishment, the apocalypse, is inevitable (Carrasco 1988, p. 152; Ventura 2000, p. 169). This is what happens each year at Easter. The Policemen's chastisements of all those present at the wedding, and the utterance of esoteric incantations aim to prevent the breaking of the crosses that support the world. However, these efforts would be in vain if no new crosses could be placed. Here, we grasp the essential role of marriage, for each couple is explicitly equated to a cross. Each wedding, then, establishes additional support to avoid the world from collapsing. In an alternative version, Jesus holds the world in his arms; this explanation is similar in so far that it confirms that sinning augments the weight of the world, thus increasing the risk that it crumbles. One man, cited by Cabrera (1998, p. 14), formulates it thus:

The Chachi believe that the world rests in the hands of God. When somebody commits a crime, steals or a man has three or four women, the weight of the world augments. Consequently, God gets tired. When He moves His hand a little this produces an earthquake. The Chachi conclude marriages to prevent such movements. [My translation]

In presumably more ancient versions crosses and Christian imagery in general are entirely absent. In some accounts, for instance, the world is not kept in the hand of Jesus or God, but in that of a gigantic creature known as « the one that holds the world with its hand (tyaapachi tana'tu; Carrasco 1988, p. 134). In one version, each couple is identified with a particular kind of cord made from fibres obtained from royal palms (Roystonea spp.). The latter version refers to Tutsá, the Chachi's mythical village of origin located in the middle of the world, exactly at the spot where it «threatens to break into two halves ». Narrators assert that underneath the path leading to that village, it is exactly such cords that keep the world together (Medina 1997, p. 59). The at first sight incongruous link between catastrophes and weddings, but also the frantic persecution of adulterers is now better understandable. While the imagery is to some extent variable, especially with regards to the use of Christian elements, the same idea always recurs. The married couple, as a whole, is equated to a cross or a cord, supporting the world or preventing it from falling apart. Each time a marriage fails, a cross breaks or a cord snaps, thereby bringing the end of the world closer. To conclude a marriage, on the other hand, is always a bit of a salvation.

Clearly, it is a mistake to explain Chachi attitudes towards adultery and their stress on monogamous marriage as an inheritance from their contacts with 
Catholic missionaries, as some of my predecessors have done (e.g. Altschuler 1964). We now understand that the adoption of Christian imagery like crosses did not necessarily imply a radical rupture with previous beliefs and practices. The overlap between Chachi and Spanish-Catholic conceptions about marital faith results more likely from coincidence than from imposition. The priests who attempted to convert the Chachi since the early 16 th century maybe managed to alter the form of their metamorphic practices, but not the metamorphic practices themselves. I would like to stress once more that the wedding couple, whether associated with a cross or a cord made from royal palm fibre, adopt a monstrous status: Hispanic priests and cross bearers are referred to as uyala, nowadays usually translated as « whites » but originally meaning " man-eaters ». Although its etymology is unknown, the royal palm appears to have a similar connotation, as its vernacular name is uyachi, which could tentatively be translated as " maneater tree ». These associations reinforce the thesis that the newlyweds are temporarily non-Human just like the other wedding participants. What remains to be clarified is why this would be so; in other words: why metamorphosis? Before answering this question, it is useful to recap a few things. At the Easter festival, we observe a fundamental reversal: the ordinary world of Humans becomes catastrophic and the catastrophic world of Monsters and the Dead becomes ordinary. When the Chachi leave their villages and congregate in the ceremonial centre one could say that all Humans have been exterminated; the world has come to an end and all that remains are non-Humans. In fact, the rationale is not so different from what happens in Amerindian shamanism more widely: the idea appears to be that one can only beat the monstrous by temporarily joining it. As Viveiros de Castro and those who elaborated on his approach have hinted at, the precondition to control and eventually overcome one's adversary is to adopt a similar perspective. The strategy is not one of avoidance; rather; it is based on what one could term "neutralization by co-option ». At Chachi weddings, I argue, this only happens on a larger scale: we are not talking about the metamorphosis of an individual shaman, hunter or warrior but about that of an entire population. I have shown that participation in the festival entails a shift from the Human into the non-Human, from restrained and peaceful Chachi into exuberant and aggressive Monsters. Such collective metamorphoses are disasters, but they are curbed disasters, kept within certain bounds. The key assumption is that catastrophes are fundamentally unavoidable; therefore, trying to escape them is pointless and completely annihilating them impossible. Instead, Chachi people have chosen to co-opt catastrophes in order to "live with them » and wedding festivals are the original instrument they have developed for this purpose.

To conclude, I briefly comment on what this particular case contributes to our knowledge about «millenarianism » in South America more generally. If one considers the ritual occasions described in the ethnography of South America, it is not difficult to point to parallels with what I have outlined in the present study. 
For example, what Gow (2001, pp. 158-187) says about Piro initiation ceremonies, where celebrants paint themselves as jaguars or dress up as white people, use esoteric language and copiously consume tobacco and alcohol is strikingly similar to what happens at Chachi wedding festivals. Not only in the Amazonian lowlands but also in the Andean highlands one comes across interesting parallels. Frank Salomon's (1981) work on the yumbada dance rituals of northern Ecuador is a good example. During such occasions Quichua dancers dress up as « wild Indians » from the tropical lowlands and as all kinds of evil creatures and predatory animals. Such rituals also involve whipping, smoking tobacco and drinking rum. Obviously, it would be worth investigating whether such practices entail a metamorphosis from the Human into the non-Human, as I have proposed concerning Chachi weddings. What we know for sure is that apocalyptic ideas are omnipresent among Amerindian people throughout the continent; however, why this would be so remains unanswered. The present study indicates a possible pathway: if it is true that Chachi weddings are catastrophes, the bigger question that arises is whether this is a unique ethnographic oddity or a specific instance of a much wider phenomenon we encounter all over the continent. To formulate this in a more tentative way: in how far can we say that the occasions which South America specialists usually describe as « rituals » are catastrophes? Finding out to what extent shape-shifting from the Human into the Monstrous is common among Amerindians emerges as a promising challenge for future research. *

* Manuscrit reçu en août 2007, accepté pour publication en septembre 2008.

\section{NOTES}

I thank Laura Rival, Elizabeth Ewart, Philippe Erikson, Armelle Lorcy and Anna Boermel for their comments on an earlier version of this paper. I gratefully acknowledge the support of the Wenner-Gren Foundation (Gr. 7173), the Royal Anthropological Institute, CNRS (Legs Lelong) and the Economic and Social Research Council (Grant PTA-026-27-1574).

1. The elderly say: «A glass of water can save your life ». When you drink water, to be sure, you touch the glass gently; it is almost as if you give it a kiss. Grateful for this tenderness, it is said to come to one's help in emergency situations.

2. Even nowadays, when there is a heavy storm and children are afraid, they are sometimes advised to hold a piece of balsa.

3. The Chachi call this practice miseecuya (from the Spanish misericordia). "God-the-Father » is a literal translation of the vernacular term diusapa.

4. At present such children's weddings no longer take place, but in the not so distant past they were all but a rarity. Most of my elderly informants remembered such occasions from their youth.

5. At the celebrations that I witnessed, the organizers spent from $\$ 100$ up to $\$ 300$.

6. In this article, I focus on the Easter ceremonies. Although they have a lot in common with what happens at Christmas, I should make it clear that both are not entirely identical.

7. If the prospective dancer was a woman, the procedure developed inversely. Like the brides, female dancers were wrapped up in a veil and had to put on a ceremonial dress. 
8. Chaitaruku literally means " man with the baton "; in local Spanish it is translated as policia.

9. In the version related to me, the bride transformed into a dog and copulated with her former lover behind the back of the groom.

10. In this case " mistake » especially refers to breaches of monogamy; each time it is discovered that somebody has an extramarital affair, a Policeman is called upon. The punishment usually consists of whiplashes or putting the " wrongdoers » in the stocks (in a forthcoming article I treat this issue in more depth).

11. I use capital letters to indicate that these expressions refer to what I call « shape », a notion that will be explained in more depth further onwards.

12. During death rituals and shamanic curing rites, money, rum and tobacco also play a prominent role.

13. This is an example of what Eduardo Viveiros de Castro (1998) has referred to as the " ethnocentrism " of Amerindian peoples. The phenomenon is widespread and was already noted by Claude Lévi-Strauss (1962, p. 220).

14. This approach is in accordance with Philippe Descola's $(2005, \mathrm{p}$. 197) remark that many if not most Amerindian ethnonyms can literally be translated as « the people » or " the human beings » and that therefore " ils sont un marqueur d'énonciation et non un nom ».

15. For a more complete overview of Chachi mythology I refer to my doctoral thesis (Praet 2006, pp. 20-121 and appendixes) and to a forthcoming publication specifically dedicated to that theme.

16. In this context "worthy " specifically refers to "monogamous»: being faithful to one's husband or wife is a sine qua non to qualify as a proper Chachi (Praet 2006, 2009).

17. More specifically, the grooms appear to become drumming ghosts. The latter are often described as carrying two big whips cross-wise over their shoulders. The red ribbons with which the grooms are adorned are also worn cross-wise over the shoulders. Moreover, in some myths drumming ghosts have red hats, while the grooms wear red head ribbons or put a red handkerchief on their head.

\section{REFERENCES CITED}

\section{Altschuler Milton}

1964 The Cayapa: a study in legal behavior, $\mathrm{PhD}$, University of Minnesota, Minneapolis.

\section{BARRETT Samuel}

1925 The Cayapa indians of Ecuador, Museum of the American Indian, Heye Foundation, New York.

\section{CABRERA Ramiro}

1998 Medicina tradicional chachi, Proyecto de Manejo Forestal Sostenible/ Endesa/Botrosa, Quito.

\section{CARrasco Eulalia}

1988 El Pueblo chachi. Eljeengume avanza, Abya-Yala, Quito.

Curnow Timothy J. and Anthony J. LidDicont

1998 "The Barbacoan languages of Colombia and Ecuador », Anthropological Linguistics, 40 (3), pp. 384-408. 


\section{DeBoer Warren}

1997 «Ceremonial centres from the Cayapas (Esmeraldas, Ecuador) to Chillicothe (Ohio, USA) », Cambridge Archaeological Journal, 7 (2), pp. 225-253.

Descola Philippe

2005 Par-delà nature et culture, Éditions Gallimard, Paris.

Gow Peter

2001 An Amazonian myth and its history, Oxford University Press, Oxford.

HARRIS Olivia

1987 «De la fin du monde. Notes depuis le Nord-Potosi », Cahiers des Amériques Latines, 6, pp. 93-118.

HuGH-JoNEs Stephen

1994 "Shamans, prophets, priests and pastors", in Nicholas Thomas and Caroline Humphrey (eds), Shamanism, history and the state, University of Michigan Press, Ann Arbor, pp. 32-75.

LÉvi-STrauss Claude

1962 La Pensée sauvage, Plon, Paris.

MaCCORMaCK Sabine

1988 " Pachacuti: miracles, punishments, and last judgment: visionary past and prophetic future in early colonial Peru », American Historical Review, 93 (4), pp. 960-1006.

Medina Henry

1997 "Los chachis de Esmeraldas », in José E. Juncosa, (ed.), Etnografias minimas del Ecuador, Abya-Yala, Quito.

Praet Istvan

2005 "People into ghosts. Chachi death rituals as shape-shifting », Tipiti. Journal of the Society for the Anthropology of Lowland South America, 3 (2), pp. 131146.

2006 Courage and fear: An inquiry into Chachi shape-shifting, $\mathrm{PhD}$, University of Oxford, Oxford.

2009 "Shamanism and ritual in South America. An inquiry into Amerindian shape-shifting ", Journal of the Royal Anthropological Institute, 15 (4), pp. 737-754.

SALOMON Frank

1981 "Killing the Yumbo: a ritual drama of northern Quito ", in Norman Whitten (ed.), Cultural transformations and ethmicity in modern Ecuador, University of Illinois Press, Urbana, pp. 162-208.

Ventura Montserrat

2000 À la croisée des chemins. Identité, rapports à autrui et chamanisme chez les Tsachila de l'Équateur, thèse de doctorat, EHESS, Paris.

Viveiros de CASTro Eduardo

1998 "Cosmological deixis and Amerindian perspectivism ", Journal of the Royal Anthropological Institute, n. s. 4 (3), pp. 469-488. 


\section{WHITEHEAD Neil}

2002 Dark shamans: Kanaimá and the poetics of violent death, Duke University Press, Durham and London.

\section{WRIGHT Robin}

1992 "Guardians of the cosmos: Baniwa shamans and prophets, part I ", History of Religions, 32 (1), August, pp. 32-58.

1998 Cosmos, self and history in Baniwa religion. For those unborn, University of Texas Press, Austin.

2004 «The wicked and the wise men: witches and prophets in the history of the Northwest Amazon ", in Neil Whitehead and Robin Wright (eds), In darkness and secrecy. The anthropology of assault sorcery and witchcraft in Amazonia, Duke University Press, Durham and London, pp. 82-108. 